brazilianpoliticalsciencereview

ART I CLE

\title{
Migrant Remittances and Rights to Physical Integrity: A Cross-section Study of Latin America (1981-2014)
}

\author{
Cristiane Lucena Carneiro \\ https://orcid.org/0000-0001-5017-5173 \\ Universidade de São Paulo, São Paulo, São Paulo, Brazil \\ Ana Figueroa \\ https://orcid.org/0000-0003-4984-5074 \\ Brazilian Center of Analysis and Planning, São Paulo, São Paulo, Brazil
}

This article analyzes aspects of two ubiquitous phenomena in contemporary societies: migration and violations of rights to physical integrity. It focuses on violations of rights to physical integrity, such as torture and political assassination, that take place in the countries that migrants leave behind (home countries). This paper explores the association between migration and violent political repression via one observable aspect of migration: transfers of sums of money from migrants to individuals in their home countries. These transfers are called remittances. This article engages with the growing literature on remittances to ask whether remittances influence the protection of rights to physical integrity within migrant-sending countries. An analysis of 21 Latin American countries between 1981 and 2014 shows that remittances are associated with less protection of rights to physical integrity. Our empirical analysis reveals this unintended effect of remittances, which is mediated by political protests and elections. A case study of Haiti illustrates the association between peaks of remittances and repression.

Keywords: Remittances; human rights; Latin America; migrantsending countries; migration.

http://dx.doi.org/10.1590/1981-3821201900020004

For data replication, see: https://doi.org/10.7910/DVN/QM2Z01

This publication is registered under a CC-BY Licence. 
$\mathbf{M}$ igration and political repression are ubiquitous historical phenomena at the center of a large literature in international political economy. Whereas we know a lot about both migration and government repression, not much has been written about the relationship between the two. This article seeks to fill this gap and focuses on one observable aspect of migration: remittances. We ask whether the flow of remittances impacts the level of government repression via their influence on domestic politics. Remittances constitute financial transfers from individuals that left their countries and these financial transfers benefit individuals back home (often family members) ${ }^{1}$.

The theoretical argument advanced in this paper suggests that remittances empower domestic constituencies in migrant-sending countries (the countries that the migrants leave behind) by improving the economic well-being of these groups, thereby making them more self-sufficient. Once these groups no longer depend on the government for their basic needs, they assume a more vocal political attitude. As a consequence, domestic constituents empowered by remittances increase their political demands of the government. When governments renege on these demands, newly empowered constituents take to the streets to protest. Governments resort to repression in order to contain protests and signal their strength. Violent political repression entails more violations of rights to physical integrity.

The article relies on two observable aspects of migration and repression (the level of migrant remittances and the level of protection of rights to physical integrity) in order to explore a possible association between migration and political repression ${ }^{2}$. Remittances are our main explanatory variable and violent political repression is our main dependent variable, which we measure by the protection of rights to physical integrity.

This analysis builds on prior research that has documented the impact of remittances on the likelihood of democratic transition, or democratization, and its

\footnotetext{
${ }^{1}$ Remittances are personal transfers of money or similar values between resident and non-resident households, or money that migrants send to their families back home.

${ }^{2}$ Rights to physical integrity haves been the subject of legal analysis in international, regional, and constitutional instruments. These rights can be summarized as the right to life and the prohibition of torture.
} 
relation to electoral cycles within the migrant-sending country. Recent research has studied the impacts and consequences of remittances on domestic politics and found that remittances increase the likelihood of democratization by reducing support for the incumbent regime. This impact is most noticeable in autocracies and dominant-party-regimes in general (ESCRIBÀ-FOLCH et al., 2015; MESEGUER and BURGESS, 2014). With respect to remittances and electoral cycles, elections present migrants with an opportunity to directly engage with the political process through contributions to political campaigns, their own votes, and often through the votes of their family members. Remittance flows are known to increase during election years; they increase even more when neither the incumbent nor his/her appointed successor is running (O'MAHONY, 2013) ${ }^{3}$. In parallel, and unintentionally, remittances occur in tandem with more violations of rights to physical integrity as a consequence of government repression.

Remittances are not the first well-regarded international policy instrument to be associated with higher levels of government repression. We now know that economic and targeted sanctions have similar impacts on rights to physical integrity (CARNEIRO and APOLINÁRIO, 2015; WOOD, 2008). World Bank structural adjustment agreements and IMF conditionality also negatively influence the protection of human rights (ABOUHARB and CINGRANELLI, 2006). Underlying the causal mechanisms in all these instances, processes of democratization have been found to be incidentally associated with greater levels of political repression as well (MESQUITA et al., 2005; DAVENPORT, 2004), also through their adverse effects on economic growth (MESQUITA et al., 2003). Along the same lines, peacekeeping operations can also bring about lower levels of respect for human rights (MURDIE and DAVIS, 2010).

The next section of this paper taps into the causal mechanisms discussed in some of these studies and presents our expectations about how remittances influence violent political repression within migrant-sending countries, proposing a set of hypotheses. This is followed by an empirical analysis, a case study of Haiti, and the conclusion.

\footnotetext{
3Migrants become more motivated to send remittances when they believe that their contribution can make a difference. O'Mahony (2013) finds that remittances increase by 6.6 percent during election years and by $12 \%$, for elections when the incumbent is not running.
} 


\section{Background and theory}

In 2014, remittances accounted for almost 1\% of Latin American countries' GDP on average, according to the World Bank. Even though this is less than its peak in 2003, remittances still are a very important source of revenue for migrantsending countries in the region. In fact, remittances amount to more than foreign direct investment (FDI) and government aid in some of these countries. Unlike FDI and government aid, for practical purposes, remittances constitute a non-taxable source of income, and directly accrue economic and political capital for individual recipients (ESCRIBÀ-FOLCH et al., 2015).

Figure 01. Remittance flows vs. foreign direct investment and government aid in Latin America and the Caribbean (1976 - 2014)

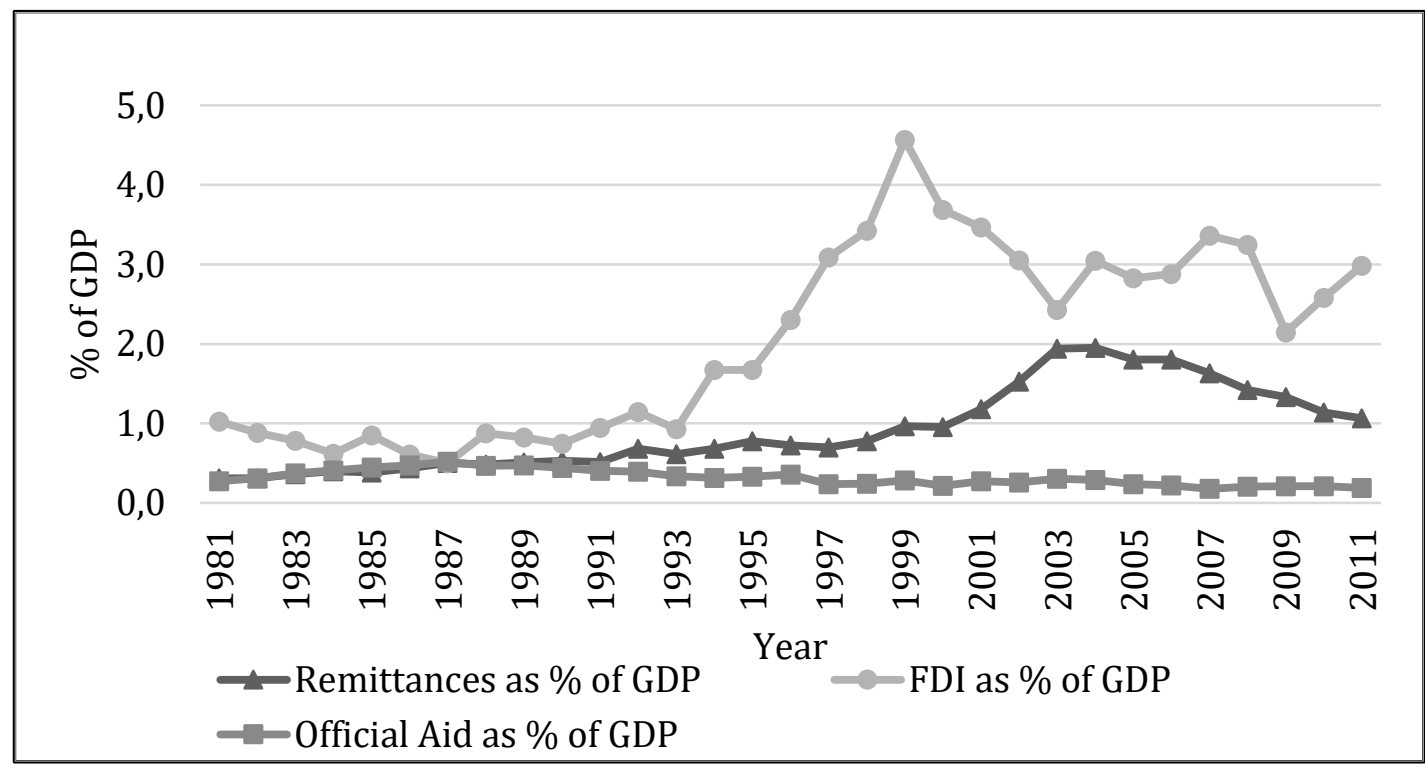

Source: World Development Indicators, World Bank (2017).

The situation with respect to human rights is equally eye-catching. In 2014, ten Latin American countries were still considered 'partly free' by Freedom House, with one, Cuba, categorized as 'not free'. This represents a modest improvement from the situation ten years before, when ten countries were 'partly free' and two were 'not free'. Far from suggesting a direct link between remittance flows and the protection of rights in Latin America, this section seeks to explore the microfoundations of these two processes. We look to explain how remittances are 
associated with changes in the protection of one category of human rights: rights to physical integrity.

Latin America is a particularly well-suited region for exploring the relationship between remittances and human rights because Latin American countries have actively sent migrants to other countries throughout the second half of the $20^{\text {th }}$ century and the early decades of the $21^{\text {st }}$. These countries have consistently experienced acute problems with human rights, despite a dense net of legal instruments at the constitutional and international levels that are dedicated to protecting them. In fact, Latin American countries were among the first countries to create regional legal instruments dedicated to protecting human rights.

In 1948, several months before the ratification of the United Nations' Universal Declaration on Human Rights, countries in Latin America signed the American Declaration on the Rights and Duties of Man. This was followed by the development of a dense net of treaties and institutions that culminated with the Inter-American Human Rights System that is currently in place (CARNEIRO, 2019). Nowadays, the Inter-American System comprises a human rights convention and court that operate in concert with a human rights commission and a network of regional treaties that specify rights and protections against, among other things, torture. The Inter-American Human Rights System overlaps with the United Nations Human Rights System, which has been very prominent in the region since the 1970s and 1980s, when the regional regime was still evolving. Most countries in the region are members of the 1996 International Covenant on Civil and Political Rights as well as the 1984 Convention Against Torture. At the international level, these are the most relevant treaties vis-à-vis the protection of rights to physical integrity.

Latin America is also a good place for observing the impact of democratization processes and electoral cycles on human rights because both of these phenomena have taken place frequently in the region during the 1981-2014 period. The next sections analyze how remittances affect the protection of human rights, with an emphasis on rights to physical integrity, via two phenomena: protest and elections. These sections discuss the theoretical underpinnings of these phenomena, and use them to derive two hypotheses. 


\section{Remittances, political empowerment, and protest}

According to the literature, migrant remittances have three important consequences for remittance-receiving households: they bring about economic empowerment, they promote political mobilization and are associated with a decrease in government social spending within migrant-sending countries. These consequences have been extensively studied by the literature on remittances, as we show in the next few paragraphs.

Studies that have documented the effects of remittances on democratization have proposed two mechanisms for explaining this relationship. First, remittances empower recipient households economically, thereby weakening their dependence on clientelistic political structures. Once individuals realize that they are no longer tied to patronage systems sponsored by authoritarian regimes, they can exercise their exit and voice options more readily (HIRSCHMAN, 1978 as cited in ESCRIBÀ-FOLCH et al., 2015). Second, remittances also can include contributions to opposition forces. We know that migrants increase remittances during election years, and studies suggest that migrants are motivated by the opportunity to influence the political process via their support of opposition parties (ESCRIBÀ-FOLCH et al., 2015; O'MAHONY, 2013). A stronger opposition (challenger) constitutes a threat to incumbent survival, thereby increasing the probability of democratization (MESQUITA et al., 2003; ESCRIBÀFOLCH et al., 2015).

According to the literature, remittances lead to greater political demands as individuals that belong to remittance-receiving families may now choose to 'voice' their political preferences. The causal path for this relationship has only recently been revealed by political economists and sociologists, who have provided evidence of remittances' effect on political mobilization within migrant-sending households with both qualitative work (BURGESS, 2012; MESEGUER and APARICIO, 2012a, 2012b) and quantitative work (NYBLADE and O'MAHONY, 2014; O'MAHONY, 2013). This literature documents how economic remittances enhance social capital within migrant-sending countries. Córdova and Hiskey (2015) have analyzed the micro-foundations that inform the observed relationship between economic remittances and social capital within migrant-sending countries. 
Córdova and Hiskey's (2015) findings go hand-in-hand with research that has analyzed the impact of migrant remittances on social spending within migrantsending countries. Doyle (2015), for instance, shows how remittances lead to lower levels of government social spending within migrant-sending countries. In both cases, the end result is higher levels of individual empowerment, which leads to greater political demands on the state. Further research on this area is needed, and scholars have started to explore this phenomenon by looking at authoritarian regimes.

Governments respond to the political empowerment associated with remittances in consistently self-motivated ways, with the goal of maximizing their chances of political survival. Governments' responses mirror welldocumented patterns of behavior in other arenas, including economic sanctions, World Bank and IMF programs, and peacekeeping operations (ABOUHARB and CINGRANELLI, 2006; CARNEIRO and APOLINÁRIO, 2015; MURDIE and DAVIS, 2010; WOOD, 2008). In the case of sanctions, aid, loans, and UN peacekeeping, the adverse consequences of protecting rights to physical integrity are just as important (albeit unintended). Political survival is a key incentive behind governments' reactions. With respect to remittances, we argue that incumbents perceive increased demands by remittance-recipient households as threats to their political survival. Faced with these threats to their tenure in power, they mobilize the repressive apparatus of the state, generating more violations of rights to physical integrity ${ }^{4}$.

As a consequence, we should observe a relationship between remittances and repression, mediated by a relationship between remittances and protests. This expectation leads to the following hypothesis:

H1: Remittances are associated with less government respect for rights to physical integrity.

\footnotetext{
${ }^{4}$ The selectorate model assumes that every leader faces a challenger who is constantly competing to attract defectors from the group of individuals that is essential for the political survival of the leader. This group of individuals - or the winning coalition - is key to understanding the dynamics of transitions to democracy, and will grow disproportionately to a point where the loyalty between each member and the leader wanes and defection to a challenger becomes more likely. This offers one explanation for the higher levels of government repression that accompany democratization processes.
} 


\section{Remittances and electoral cycles}

The potential impact of remittances on the protection of rights to physical integrity is also influenced by electoral cycles in migrant-sending countries. Previous research has analyzed the sensitivity of political remittance flows to instrumental and non-instrumental motivations and concluded that, on the one hand, instrumental motivation leads migrants to increase political remittances during electoral years, particularly when elections are contested. Migrants perceive this scenario as an opportunity to make an impact on the outcome of the election. On the other hand, the literature also addresses the role of noninstrumental political motivations, finding that migrants become more engaged with domestic politics within their countries of origin during election years, paying closer attention to issues in political debates, political parties, and election media coverage. As a result of these instrumental and non-instrumental motivations, migrants tend to increase remittances to their home countries around the time of elections (O'MAHONY, 2013).

Remittances also empower selectorates through direct transfers that reduce citizens' dependence on public goods provided by the government, thereby reducing loyalty to the incumbent (MESQUITA et al., 2003). Diasporas care deeply about the situation back home, and remittances sent during election years can help dissent groups and hometown associations (HTAs) who support specific candidates, often newcomers to politics. Eventually, a new winning coalition may arise around the newcomer. If elections are highly contested, migrants will show greater interest in them and increase remittances in order to strengthen their candidate. This scenario entails threats to incumbent political survival and may be associated with protests and government repression. One example of this was Sri Lanka's Liberation Tigers of Tamil Eelam (LTTE), who have historically relied on diasporas to accrue financial capital (POLICZER, 2006). We capture the impact of protests and elections by including them as controls in our empirical section.

For the purposes of our research question, election years are associated with more political protest in the form of anti-government demonstrations, general strikes, and riots. This is especially true in democratizing states. We therefore expect the association between remittances and violations of rights to physical integrity to 
be stronger during election years. This expectation leads to the following hypothesis:

H2: The negative association between remittances and the protection of rights to physical integrity is stronger during election years.

The association between migrant remittances and protests against the government is therefore multifaceted. Figure 02, below, captures the three phenomena that help increase the level of anti-government protests according to our argument. Because these three phenomena are well-documented in the literature, we treat them as heuristics in this project.

Figure 02. Causal mechanism

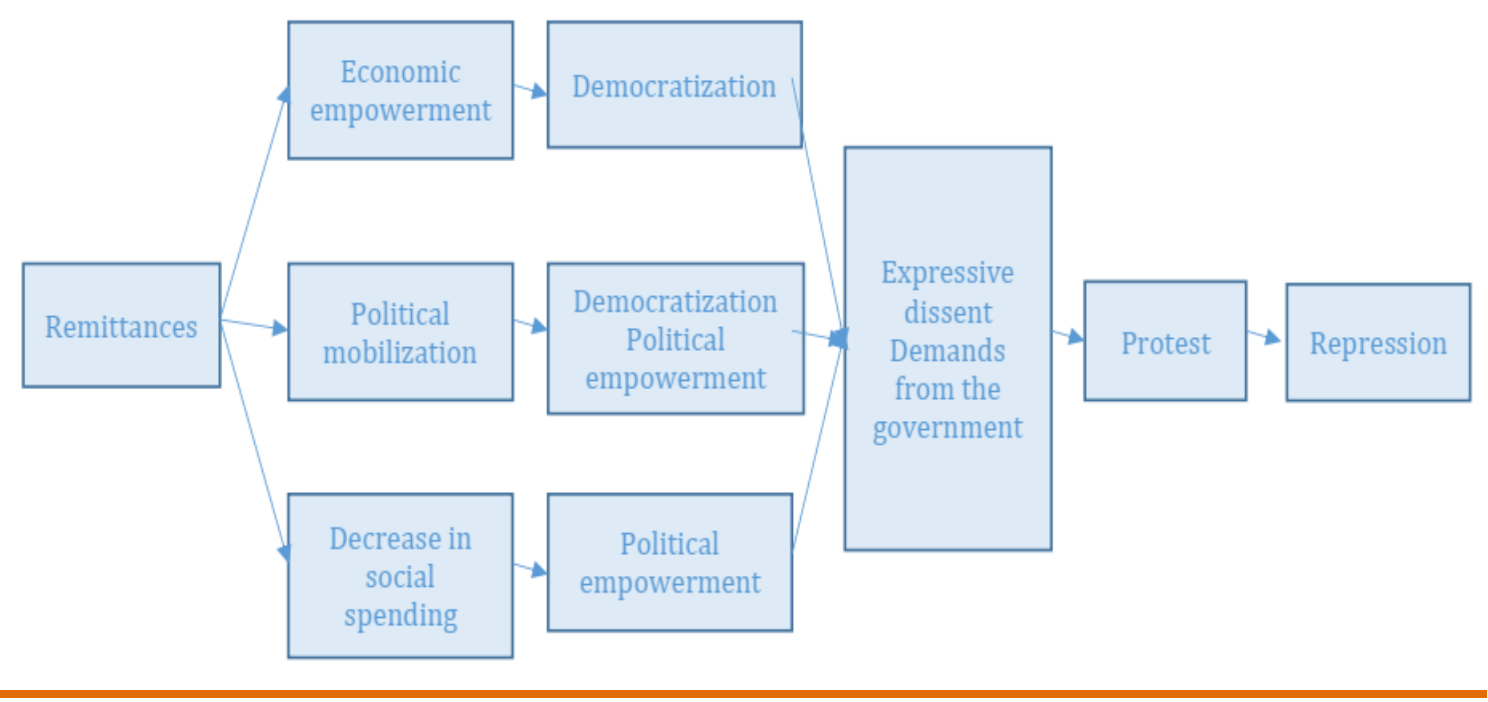

Source: Elaborated by the authors.

Figure 02 presents three immediate consequences of remittances within migrant-sending countries according to the literature: 01. economic development, 02. political mobilization, and 03. decreases in social spending. Based on findings in the political economy of development literature, we now know that democratization and political empowerment are often associated with these three consequences. Once constituents no longer depend on the government for their basic needs (because remittances provide sustained relief) these individuals are no longer bound by clientelistic handcuffs. They can afford to disagree with the incumbent, demand more of a political voice, and mobilize the wheels of democracy. We propose measuring these new forms of behavior as democratization and political empowerment. 
In the next section, we show how constituents engage in expressive dissent and formulate (or not) demands of the government. Either one of these behaviors - themselves a direct consequence of democratization and political empowerment - is a sufficient condition for protest when they are resisted by the incumbent. The outcome in Figure 02 is repression, our dependent variable.

\section{Consequences of remittances for the protection of rights to physical integrity}

Our empirical analysis relies on panel data for twenty-one countries in Latin America with populations greater than 500,000, covering 1981 to 2014 for a total of 689 country-year observations on the protection rights to physical integrity, remittances, and several control variables and instruments. The World Bank defines remittances as personal transfers of money or similar values between resident and non-resident households, that is, money that migrants send to their families back home. Levels of remittances are the main explanatory variable in this study.

In order to assess the two hypotheses introduced above, we estimate a model to investigate the remittances' impact on the protection of rights to physical integrity. The dependent variable is the level of protection of rights to physical integrity for a single country at any given year; it is measured by country 'i's' score on the CIRI scale at time ' $t$ '. The scale measures the level of respect for rights to physical integrity by country-year based on annual reports on human rights from the U.S. Department of State ${ }^{5}$. The scale ranges from 0 (no respect) to 08 (full respect). To make interpretation easier, we inverted the scale so that higher scores correspond to more violations of human rights ${ }^{6}$.

The main independent variable is the level of remittances in country ' $i$ ' at time ' $t$ '. For Models 02 and 03, this variable is lagged by both one year and two years (the level of remittances in country ' $i$ ' at time 't-1' and 't-2') in order to assess the effect of remittances one and two years after being received. Because the observed

\footnotetext{
${ }^{5}$ Cingranelli, David L.; David L. Richards, and K. Chad Clay (2014), The CIRI Human Rights Dataset. $<$ http://www.humanrightsdata.com $>$. Version 2014.04.14.

${ }^{6}$ Human rights scholars are currently concerned with the time sensitivity of several measures of human rights protection. For this discussion, see Fariss (2014). We are satisfied that the CIRI dataset is less vulnerable to such problems.
} 
level of repression is influenced by repression in previous years, we include a lagged measure of repression in the model as well.

The following terms in the equation are controls that are known to influence respect for human rights. The first variable is the occurrence of international or domestic conflict, measured by each country's score in the Major Episodes of Political Violence (MEPV) dataset (MARSHALL, 2015). We expect to see a direct relation between a country's MEPV score and its level of domestic repression (APODACA, 2007; MESQUITA et al., 2003). Second, GDP growth should be negatively correlated with political repression, so we expect higher growth rates to be associated with lower values on the CIRI scale. Third, population size is a wellknown predictor of political repression, which means that we expect to see a direct relationship between population size (measured as the natural logarithm of country 'i's' population at time ' $t$ ') and higher values on the CIRI scale (LANDMAN, 2005). Fourth, we control for the effect of regime types; this follows standard practice in the literature, which has found that democratic regimes are associated with better human rights practices, as expressed by lower scores on the CIRI scale (HILLEBRECHT, 2012; HOLLYER and ROSENDORFF, 2011; LANDMAN, 2005; POE et al., 1999; VREELAND, 2008). We rely on Polity IV's classification of regime type, which ranks countries from -10 (the most authoritarian regime) to +10 (the most democratic regime $)^{7}$. We expect an inverse relationship between country 'i's' Polity IV score at time ' $t$ ' and its CIRI score.

The next terms in the model control for economic sanctions, elections, protests, IMF adjustment agreements, trade flow, and net migration. The literature has established that both sanctions and elections have adverse effects on the protection of human rights. We focus on conventional (as opposed to targeted) sanctions. In order to capture the possible influence of sanctions on the protection of rights to physical integrity, we document every instance in which country 'i' was subject to sanctions at time 't' (HUFBAUER et al., 2007).

Elections in general are also associated with higher levels of political repression. Our analysis focuses on presidential and legislative elections, with the

\footnotetext{
${ }^{7}$ Monty Marshall and Tedd Gurr (2010), Center for Systemic Peace, at http://www.syste micpeace.org/polity/polity4.htm.
} 
elections variable equal to 01 if a country had an election in a given year and 0 otherwise. We expect to find a direct relationship between the presence of elections in a given year and high levels of repression, as measured by a higher CIRI score. Data on elections comes from the National Elections Across Democracy and Autocracy Dataset (NELDA) (HYDE and MARINOV, 2012). Our third control variable measures the incidence of protests, which, according to the literature, increases the likelihood of repression. These data come from the Major Events of Political Violence dataset, with the variable equaling 01 if a country experienced protest in a given year and 0 otherwise. The literature has also documented the adverse consequences on human rights of IMF conditionality and World Bank loans (ABOUHARB and CINGRANELLI, 2009; 2006). In order to control for these intervening factors, we incorporate dummy variables to identify every year in the dataset in which a country was a contracting party under a valid IMF/World Bank loan program.

These data come from the History of Lending Arrangements dataset from the International Monetary Fund. Finally, we also control for net migration in order to investigate a possible consequence of out-migration on the composition of the politically engaged segment of the population. According to the World Bank, net migration equals the total number of immigrants minus the annual number of emigrants.

Table 01 presents descriptive statistics for the variables used in the statistical analysis. It also indicates the expected relationship between the independent variables and the dependent variable, which measures the level of protection rights to physical integrity. Appendix A shows a test of collinearity; there is no multicollinearity among our independent variables.

Given the nature of our dependent variable, we estimated ordered logistic regressions, which are the models best equipped to analyze categorical dependent variables. We perform our regressions at time ' $t$ ', with additional regressions at time 't-1' and 't-2' to account for possible lagged effects from previous years (BECK and KATZ, 2011; WILKINS, 2018). All models include a full set of country fixed effects.

The models are estimated using the following equation:

(1) $\quad$ Ciri $_{i t}=\beta_{1}$ lag_Cirit $-1_{-}+\beta_{2}$ remitt_gdp $_{\text {it }}+\beta_{3}$ mepv $_{\text {it }}+\beta_{4}$ imf $_{\text {it }}+\beta_{5}$ gdpgrowth $_{\text {it }}+\beta_{6}$ $\operatorname{logpop}_{i t}+\beta_{7}$ democracy $_{i t}+\beta_{8}$ sanction $_{\text {it }}+\beta_{9}$ elections $_{\text {it }}+\beta_{10}$ protest $_{\text {it }}+\beta_{10}$ trade it + $\beta_{11}$ netmigration $_{\text {it }}+\mathrm{FEc}+$ constant $_{i t}+\mathrm{u}_{\mathrm{i}}+\mathrm{e}_{\mathrm{it}}$ 
Table 01. Summary statistics of variables used to calculate the effect of remittances on the level of violations of rights to physical integrity (1981-2014)

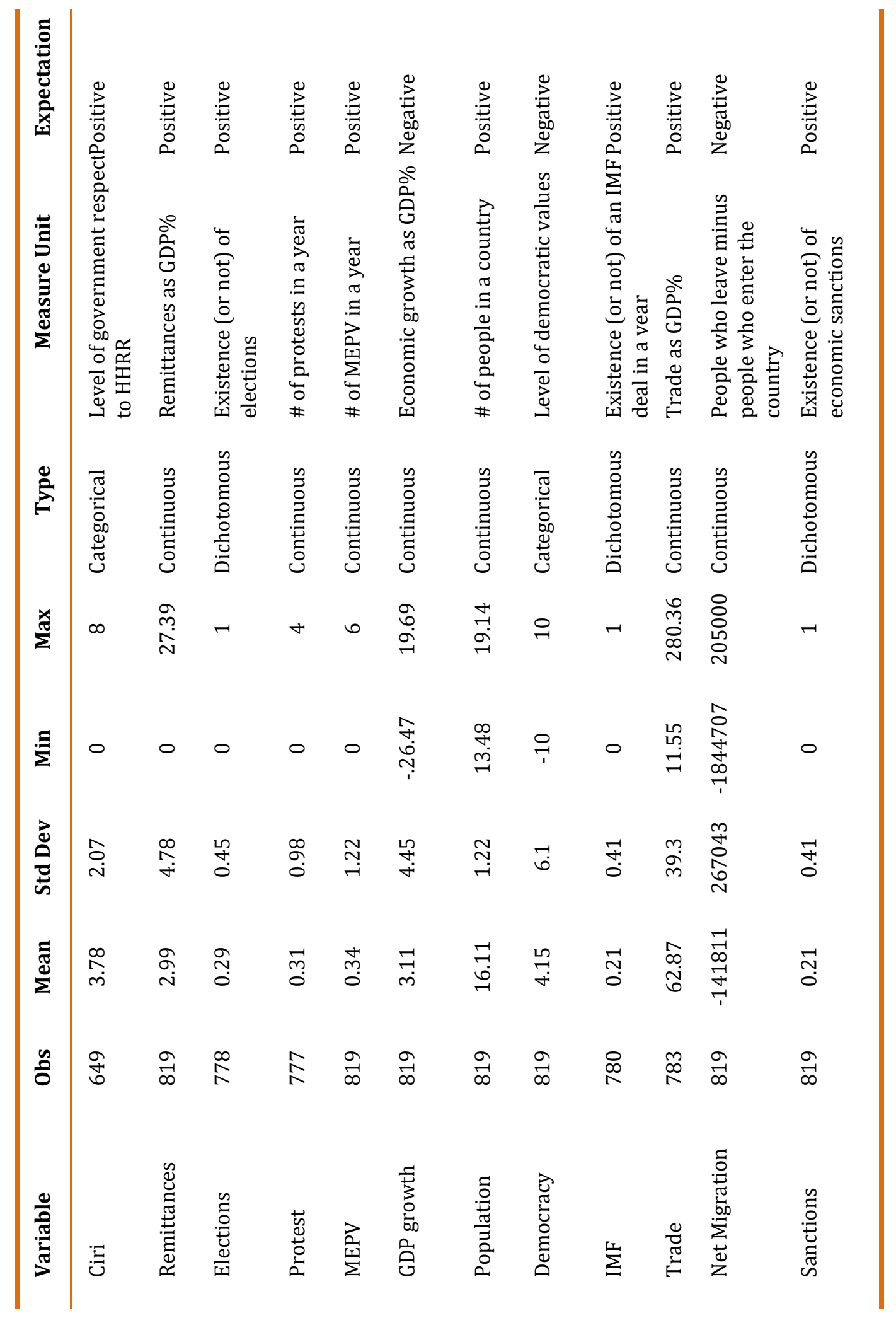

Source: Prepared by the author. 


\section{Analysis and results}

Our analysis confirmed our hypotheses. Table 02 presents results for our three ordered logit regressions. The coefficient for our main explanatory variable has the expected sign and is statistically significant; most of the controls follow the same pattern.

Model 01 shows the results for the impact of remittances on the level of violations of rights to physical integrity at time ' $t$ '. In this model, the coefficient for violations in the previous year is significant, explaining repression in the present. The coefficient for remittances, measured as a percentage of GDP (the main explanatory variable in this study) has the expected sign and is significant, indicating that as remittances increase, migrant-sending countries see more violations of rights to physical integrity. The results for Models 02 and 03 are consistent with the findings in Model 01. Moreover, remittances' effect on repression grows slightly over time (from the year in which the remittances were sent to two years after them). Several control variables, such as political violence and democracy, have the sign we expected and reach statistical significance.

One should note that political violence and democracy are highly significant and have the predicted sign across all three models. The variable that measures protests has the expected sign in all three models and reaches statistical significance in Models 01 and 03. Protests, together with political violence and prior repression (lagged CIRI) are responsible for an important share of the variation in the levels of repression, as expressed by the coefficients associated with these variables in Model 01: 0.71 (protest), 0.72 (political violence), and 0.59 (prior repression). Nevertheless, the impact of our main explanatory variable - remittances as a percentage of GDP - remains important. This impact ranges from 05 to 07 percent, which is not trivial.

All these results are robust to other specifications, such as an ordinary least squares estimator and panel-corrected standard errors. The coefficient for remittances remains positive and statistically significant across the three methods we used ${ }^{8}$.

\footnotetext{
${ }^{8}$ These results were not included due to space. They are, however, available from the authors upon request.
} 
Table 02. Effect of remittances on the level of violations of rights to physical integrity (1981 - 2014)

\begin{tabular}{|c|c|c|c|}
\hline & Ciri & Ciri & Ciri \\
\hline & Time $t$ & Time t-1 & Time $\mathrm{t}-2$ \\
\hline \multirow[t]{2}{*}{ lag_Ciri } & $0.597^{* * *}$ & $0.606^{* * *}$ & $0.473^{* * *}$ \\
\hline & $(0.068)$ & $(0.070)$ & $(0.069)$ \\
\hline \multirow[t]{2}{*}{ Remittances } & $0.0541^{* *}$ & 0.0499* & $0.0719 * *$ \\
\hline & $(0.027)$ & $(0.027)$ & $(0.029)$ \\
\hline \multirow[t]{2}{*}{ Mepv } & $0.725^{* * *}$ & $0.606^{* * *}$ & $0.608^{* * *}$ \\
\hline & $(0.111)$ & (0.109) & $(0.112)$ \\
\hline \multirow[t]{2}{*}{ Protest } & $0.718^{* * *}$ & 0.276 & $0.431 * *$ \\
\hline & $(0.228)$ & $(0.215)$ & $(0.210)$ \\
\hline \multirow[t]{2}{*}{ Elections } & -0.211 & 0.183 & -0.121 \\
\hline & $(0.170)$ & $(0.172)$ & $(0.174)$ \\
\hline \multirow[t]{2}{*}{ Democracy } & $-0.0844^{* *}$ & $-0.101^{* * *}$ & $-0.109^{* * *}$ \\
\hline & $(0.026)$ & $(0.026)$ & $(0.027)$ \\
\hline \multirow[t]{2}{*}{ NetMigrat } & 0.00 & 0.00 & 0.00 \\
\hline & $(0.000)$ & $(0.000)$ & $(0.000)$ \\
\hline \multirow[t]{2}{*}{ Population } & 0.537 & 0.418 & -0.519 \\
\hline & $(0.681)$ & $(0.665)$ & $(0.690)$ \\
\hline \multirow[t]{2}{*}{ GDP Growth } & $(0.03)$ & $(0.02)$ & $(0.02)$ \\
\hline & $(0.021)$ & $(0.020)$ & $(0.020)$ \\
\hline \multirow[t]{2}{*}{ Trade } & 0.0026 & 0.00244 & 0.00628 \\
\hline & (0.005) & $(0.005)$ & $(0.005)$ \\
\hline \multirow[t]{2}{*}{ IMF } & $(0.09)$ & 0.14 & $(0.22)$ \\
\hline & (0.195) & $(0.190)$ & $(0.192)$ \\
\hline \multirow[t]{2}{*}{ Sanctions } & 0.321 & 0.292 & $-0.549^{*}$ \\
\hline & $(0.321)$ & $(0.308)$ & $(0.322)$ \\
\hline $\mathrm{N}$ & 578 & 626 & 626 \\
\hline $\mathrm{R}^{2}$ & 0.30 & 0.30 & 0.28 \\
\hline
\end{tabular}

Source: Prepared by the authors.

Note: Standard errors in parentheses ${ }^{*} \mathrm{p}<0.10,{ }^{* *} \mathrm{p}<0.05,{ }^{* * *} \mathrm{p}<0.01$. Ordered Logistic Regression. Fixed effects not reported in this table.

In order to further disentangle the unintended adverse consequences of remittances on the protection of rights to physical integrity, we look at the predicted change in the CIRI scale that is associated with specific thresholds of remittances. In other words, how many remittances are required in order to observe a move upward along the CIRI scale? Table 03 displays the predicted probability of change in the level of protection associated with pre-determined levels of remittances. More 
specifically, we calculate the predicted probability of change associated with an increase in remittances equal to one standard deviation and two standard deviations from the mean. The results in Table 03 come from the ordered logistic regressions in Model 01 (Table 02).

The results in Table 03 consistently show the impact of remittances on the likelihood of repression. For a country that finds itself at a CIRI score of 07 , that is, a very serious violator of human rights, the probability of remaining at 07 is greater when remittances rise to two standard deviations above the mean (0.32) as opposed to the mean (0.28). Even more telling, the probability of improving the protection of rights, or a movement from a CIRI score of 07 to 06 , is smaller when remittances rise to two standard deviations above the mean (0.29) than when remittances are at the mean (0.32). Along the same lines, the probability of moving from 07 to 08 increases when remittances rise to two standard deviations above the mean (0.17), in comparison to the case when remittances are at the mean (0.12). The same trend holds for lower levels of repression as well. For example, in a country where the CIRI score is 05 , the probability of moving to 06 increases as the level of remittances rises, while the probability of moving to a score of 04 decreases consistently as remittances increase to one and two standard deviations above the mean.

To further analyze the impact of remittances on violations of rights to physical integrity, we grouped the observations into four quantiles, according to the observed levels of repression and performed quantile regressions. The results confirm that the relationship between the explanatory variable and the dependent variable is not constant across our distribution (Table 04). This analysis reveals that the impact of remittances on violations of rights to physical integrity is higher at the $50^{\text {th }}$ and $70^{\text {th }}$ quantiles.

\section{Endogeneity}

Our empirical analysis has tested remittances' effect on violations of rights to physical integrity in Latin America. But what if the very same violations are the root cause of migration in the first place? As with many other questions in the human rights literature, our study could suffer from endogeneity. We follow best practices in the literature to address this potential problem (DOYLE, 2015). 
Table 03. Effect of remittances on the level of violations to the rights to physical integrity (1981 2014), predicted probabilities

\begin{tabular}{lcccc} 
& \multicolumn{4}{c}{ Repression at Time 2 } \\
\hline $\begin{array}{l}\text { Repression at Time 1 } \\
\text { Pr(y=8|x) }\end{array}$ & $\operatorname{Pr}(\mathrm{y}=5 \mid \mathrm{x})$ & $\operatorname{Pr}(\mathrm{y}=6 \mid \mathrm{x})$ & $\operatorname{Pr}(\mathrm{y}=7 \mid \mathrm{x})$ & $\operatorname{Pr}(\mathrm{y}=8 \mid \mathrm{x})$ \\
Remittances = mean & 0.077 & 0.211 & 0.372 & 0.308 \\
Remittances = 1 sd & 0.069 & 0.195 & 0.371 & 0.338 \\
Remittances = 2 sd & 0.057 & 0.170 & 0.363 & 0.388 \\
$\begin{array}{l}\text { Pr(y=7|x) } \\
\text { Remittances = mean }\end{array}$ & 0.182 & 0.318 & 0.283 & 0.126 \\
Remittances = 1 sd & 0.165 & 0.311 & 0.302 & 0.143 \\
Remittances = 2 sd & 0.142 & 0.294 & 0.326 & 0.173 \\
Pr(y=6|x) & & & & \\
Remittances = mean & 0.316 & 0.249 & 0.109 & 0.033 \\
Remittances = 1 sd & 0.313 & 0.257 & 0.116 & 0.036 \\
Remittances = 2 sd & 0.300 & 0.280 & 0.138 & 0.045 \\
Pr(y=5|x) & & & & \\
Remittances = mean & 0.290 & 0.146 & 0.051 & 0.014 \\
Remittances = 1 sd & 0.299 & 0.159 & 0.056 & 0.016 \\
Remittances = 2 sd & 0.311 & 0.184 & 0.069 & 0.020 \\
\hline
\end{tabular}

Source: Prepared by the authors.

Note: The predicted probabilities are computed using the ordered logit estimates of Model 01 from Table 02. Repression changes are calculated on a scale of most extreme (8) to absent (0). A full table with all the results is available from the authors upon request.

Table 04. Effect of remittances on violations of rights to physical integrity (1981 - 2014), quantile regressions

\begin{tabular}{lccccc}
\hline & Ciri & Ciri & Ciri & Ciri & Ciri \\
& $\mathrm{q} 10$ & $\mathrm{q} 30$ & $\mathrm{q} 50$ & $\mathrm{q} 70$ & $\mathrm{q} 90$ \\
\hline lag_Ciri & $0.317^{* * *}$ & $0.249^{* *}$ & $0.479^{* * *}$ & $0.501^{* * *}$ & $0.526^{* * *}$ \\
& $(0.12)$ & $(0.10)$ & $(0.09)$ & $(0.05)$ & $(0.07)$ \\
Remittances & 0.0298 & 0.032 & $0.0464^{* * *}$ & $0.0259^{* *}$ & -0.0104 \\
& $(0.02)$ & $(0.02)$ & $(0.01)$ & $(0.01)$ & $(0.02)$ \\
Elections & -0.0724 & 0.097 & -0.202 & -0.211 & -0.143 \\
& $(0.18)$ & $(0.24)$ & $(0.15)$ & $(0.12)$ & $(0.22)$ \\
Protest & $0.529^{* * *}$ & $0.638^{* * *}$ & $0.519^{* * *}$ & $0.355^{* * *}$ & $0.275^{* * *}$ \\
& $(0.15)$ & $(0.13)$ & $(0.09)$ & $(0.08)$ & $(0.07)$ \\
$\mathrm{N}$ & 578 & 578 & 578 & 578 & 578 \\
$\mathrm{R}^{2}$ & 0.37 & 0.35 & 0.48 & 0.49 & 0.47 \\
\hline
\end{tabular}

Source: Prepared by the authors.

Note: Standard errors in parentheses ${ }^{*} \mathrm{p}<0.10,{ }^{* *} \mathrm{p}<0.05,{ }^{* * *} \mathrm{p}<0.01$. Ordered Logistic Regression. Control variables and fixed effects are not reported in this table.

Assuming our normal model of:

$$
\mathrm{Y}_{1}=\mathrm{Y}_{2}+\mathrm{X}_{1}+\mathrm{X}_{2}+\mathrm{u}
$$

Where $\mathrm{Y}_{1}=\mathrm{CIRI}$, and $\mathrm{Y}_{2}=$ remittances, we might question if $\mathrm{Y}_{1}$ and $\mathrm{y} \mathrm{Y}_{2}$ are endogenous. That is, could CIRI affect remittances via its impact on migration, and could remittances in turn affect CIRI? The ordered logistic regression approach is not able to address this problem and, as a result, our estimators might be biased 
upward. Therefore, an econometric approach based on instrumental variables is in order.

To that end, we re-estimated our model and performed an IV-Generalized Method of Moments approach (GMM). GMM is designed to control for endogeneity via the inclusion of lagged differences and lagged levels of the independent variables as instruments (BLUNDELL and BOND, 1998; BUCH and KUCKULENZ, 2010). We tested for endogeneity using a specification wherein the null hypothesis was that remittances could be treated as exogenous (Durbin and Wu-Hausman tests); we found that the test statistics were highly significant, indicating that our null hypothesis of exogeneity should be rejected (ILAHI and JAFAREY, 1999).

In addition to the lagged independent variables that we included as instruments, we also included two external instruments ${ }^{9}$. The first was the ratio of the distance from each country in our sample to the United States, weighted by the GDP growth of the United States (DOYLE, 2015). On the one hand, migration implies a cost, especially if the host country is far away, and the literature has proved that large distances are associated with less remittances (SINGER, 2012). On the other hand, there is no theoretical explanation for an association between the distance between each Latin American country and the United States and more violations of the right to physical integrity. The second instrument is the length of the coastline of the countries in the sample (ESCRIBÁ-FOLCH, MESEGUER and WRIGHT, 2015).

Table 05 shows the results of the GMM estimations of our models, instrumenting up to one and two lags, respectively, for the endogenous regressors. Our models accounted for 90 and 96 percent of variance of the dependent variable, as the r-squared statistic shows. Remittances' effect on violations to the rights to physical integrity is strong and highly significant, as are previous levels of violations and the level of protest. Models 02 and 03 show the results using up to one and two lags, respectively, of the endogenous regressors as instruments. The results do not vary much in the three models.

\footnotetext{
${ }^{9}$ Additional instruments help with 'weak instruments', which is a common problem in traditional GMM estimations (GERMENJI et al., 2001). We performed a standard Sargan/Hansen test for overidentifying restrictions in order to assess the validity of our instruments (BLUNDELL and BOND, 1998; ROODMAN, 2006). Based on this test, the null hypothesis that the instruments are valid cannot be rejected. The instruments are not correlated with the error term, therefore, they are correctly excluded from the estimated equation.
} 
To further address other questions about our proposed causal pathway, as well as endogeneity, we estimated a Heckman two-step model. This model implies that, in order for remittances to visibly affect CIRI, remittances in elections years are first needed. This is why remittances and elections are 'selected' as choice variables in the last part of the model. The findings show that having remittances on election years increases CIRI by 5\%, while having elections does so by $21 \%{ }^{10}$.

Table 05. Effect of remittances on the level of violations of rights to physical integrity, GMM twostep estimations

\begin{tabular}{lccc}
\hline & Ciri & Ciri & Ciri \\
\hline \multirow{2}{*}{ Lag Ciri } & & 1 -lag IV & 2 -lag IV \\
& $0.464^{* * *}$ & $0.473^{* * *}$ & $0.434^{* * *}$ \\
Remittances & $(0.04)$ & $(0.04)$ & $(0.04)$ \\
& $0.0304^{* *}$ & $0.0253^{* *}$ & $0.0292^{* *}$ \\
Elections & $(0.01)$ & $(0.01)$ & $(0.01)$ \\
& -0.139 & 0.125 & -0.107 \\
Protest & $(0.11)$ & $(0.11)$ & $(0.11)$ \\
& $0.430^{* * *}$ & $0.405^{* * *}$ & $0.455^{* * *}$ \\
$\mathrm{~N}$ & $(0.05)$ & $(0.06)$ & $(0.06)$ \\
$\mathrm{R}^{2}$ & 576 & 576 & 556 \\
\hline
\end{tabular}

Source: Prepared by the authors.

Standard errors in parentheses ${ }^{*} \mathrm{p}<0.10,{ }^{* *} \mathrm{p}<0.05,{ }^{* * *} \mathrm{p}<0.01$. Two-step GMM IV estimation. Control variables and fixed effects not reported in this table.

In the next section, we take a closer look at one Latin American country in particular: Haiti. Haiti typifies a 'hard case' in terms of its political history, which was mired in conflict, economic crises, and natural disasters. These circumstances make Haiti a good hard case for observing the effects of remittances. Nevertheless, our case study documents that remittances made a noticeable contribution to Haiti's dismal record of human rights protection.

\section{Case study: Haiti}

Haiti illustrates the importance of remittances in Latin America. The amount of remittances sent to Haiti had by far surpassed the sum of FDI and official aid over the past decade (see Figure 01). Since 2000, Haiti's level of remittances has ranged between $15 \%$ and $28 \%$ of GDP as the country experienced high levels of anti-

\footnotetext{
${ }^{10}$ These results were not included due to space. They are, however, available from the authors upon request.
} 
government protest and political violence (FAGEN, 2006). Haiti is a good place for exploring the mechanisms behind the relationship between remittances and violations of rights to physical integrity. In Haiti, because the years with the highest levels of remittances were when it reached its highest levels of violations of rights to physical integrity.

The literature has analyzed the Haitian case as an example of the interplay between out-migration and remittances, on the one hand, and the onset of civil war, on the other hand (MILLER and RITTER, 2014). One of the mechanisms that might have helped bring about political violence is the diaspora's influence on domestic perceptions of human rights. Diaspora members give groups in their home countries higher levels of protection within migrant-receiving countries; the diaspora influences incentives to protest and become more active in politics, at times via elections. As a result, Miller and Ritter (2014) argue that domestic groups within migrant-sending countries face greater costs for free-riding, which leads to higher levels of political engagement and protest (MILLER and RITTER, 2014, p. 52). This causal mechanism, which the authors support by using Haiti and Jamaica as analytical platforms, helps explain the association between remittances and rights violations that we observe in our study.

The case of Haiti also provides evidence of the positive relationship between remittances and anti-regime protests in dominant-party regimes (ESCRIBÀ-FOLCH, MESEGUER and WRIGHT, 2015). We have observed that internal conflict is likely to resume after peace settlements; this dynamic is associated with financial support in the form of remittances provided by the diaspora. According to Collier and Hoeffler (2004), diasporas' ties to politics back home make it easier for their members to offer financial support to armed groups that play roles in violence. This literature works with an underlying assumption that migrants abroad remain informed through diaspora channels of communication and mobilize to provide both material and non-material support to politically active groups, hometown associations, and dissent groups (PREST et al., 2009).

Figure 03 shows that, when comparing remittances and the CIRI scale in Haiti, the years with the highest CIRI scores coincide with higher levels of remittances, especially since 1994, when remittances increased exponentially as 
violations of the rights to physical integrity spread across the country. High levels of out-migration and remittances make Haiti a particularly good case for observing a possible association between remittances and encroachments on rights to physical integrity.

Figure 03. Remittances and CIRI in Haiti (1976-2014)

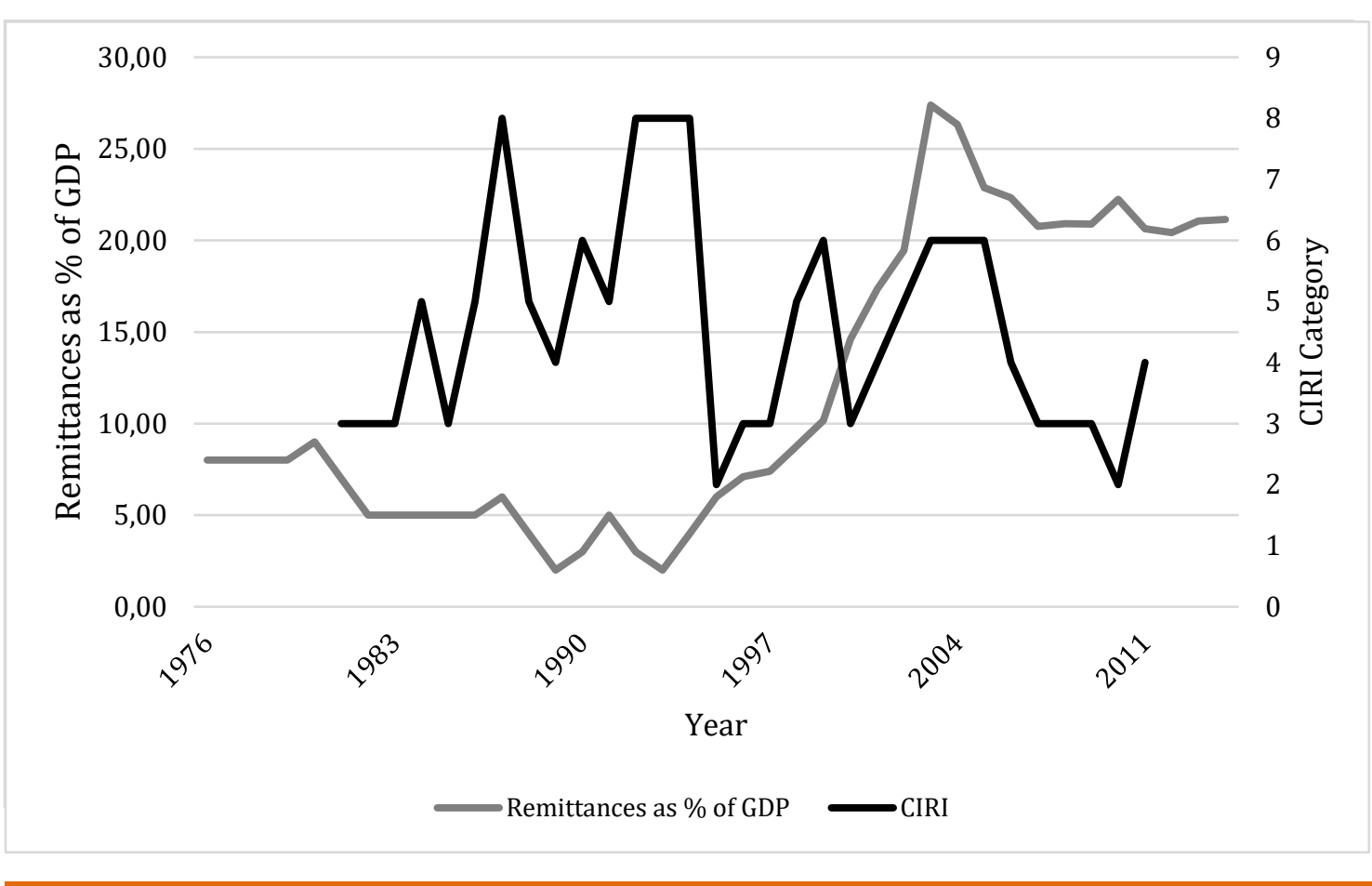

Source: World Development Indicators, World Bank (2017): Cingranelli et al., 2014.

Another question is whether individuals had joined communityimprovement collective efforts that year; among those who answered 'yes', 54.8\% received remittances as opposed to 37\%. Survey results consistently show that remittances have an impact on political engagement, as voter turnout is $11 \%$ higher among those who receive remittances. Remittance-receiving respondents also show greater levels of interest in politics. A closer look at Haiti's history can further clarify the linkage between remittances and political activism.

Haiti's recent political history constitutes a patchwork of political regimes, where virtually no elected president has completed his/her political mandate. 1986 represents the first peak in protest, when the dictator Jean-Claude Duvalier was forced out of Haiti. Four military governments ensued until the first popularly elected leader took office in 1991: President Jean-Bertrand Aristide, (GAVIGAN, 
1997). President Aristide's tenure in power was short-lived, however, as he was overthrown only six months later (QUINN, 2009). An international embargo and international sanctions were imposed on the repressive military regime that led the coup (GIBBONS, 1999). This period also coincided with an increase in out-migration flows, both by land (SCHOMBURG CENTER FOR RESEARCH IN BLACK CULTURE, 2005) ${ }^{11}$ and sea (OPISP, 1995 apud GAVIGAN, 1997) ${ }^{12}$. The concurrent peak in remittances is evidence of the economic and political concerns of the diaspora abroad. During the next three years, high levels of violence, killings, and political disappearance followed (WILSON, 2011).

A brief decrease in remittances and protests coincided with an agreement that sought to restore democracy. The Governors Island Agreement was negotiated on July 03, 1993 between Aristide and Lieutenant General Raoul Cedras, who had led the 1991 military coup (GLOBAL SECURITY, 2011). Aristide was to be restored to power by October 30,1993, but the ruling military junta would not allow it. Following the collapse of this attempt to restore democracy in Haiti, remittances and protests increased exponentially in 1994. This year also marked the U.S. military intervention, authorized by the UN Security Council. During this period, protests were widespread, as many of Aristide's allies in Haiti fought for his return, but strongly opposed U.S. military action. Members of these organizations were killed and disappeared, and thousands had to flee their homes, causing a refugee crisis (GAVIGAN, 1997; QUINN, 2009; WILSON, 2011).

'Operation Uphold Democracy' led to the reinstatement of Aristide and eventually to peaceful elections and the transfer of power on February 07, 1996. By this time, Haiti's economic situation was chaotic: unemployment had reached over $80 \%$ of the population, inflation had doubled to $50 \%$, and GDP had declined by over a

\footnotetext{
${ }^{11}$ The Schomburg Center for Research in Black Culture Haitian Immigration: $20^{\text {th }}$ Century 'In the first eight months after the coup, around 38,000 Haitians left for the United States. According to Haiti Insight, between October 29, 1991 and February 12, 1992, the United States Coast Guard spent about $\$ 45,000$ per day intercepting, housing, and returning most Haitians to their homeland'. Additionally, 10,747 Haitians were granted asylum in the United States, while 300,000 residents of Port-au-Prince migrated to the mountains and 30,000 crossed the border into the Dominican Republic, see Gavigan (1997).

${ }^{12}$ Approximately 68,000 Haitians were found at sea between the coup and the date of Aristide's return (see Open Society Institute Special Report, A Proposal to Establish a Temporary Refugee Scheme in the Caribbean Region for Refugee and Migration Emergencies, 1995).
} 
third (COUPEAU, 2008). After the re-establishment of democratic rule, the government enacted the Emergency Economic Recovery Plan (UNIR) ${ }^{13}$, which instituted privatization plans, lower tariffs, investment in infrastructure, and the rebuilding of the public sector. Additionally, the IMF approved a US\$131 million loan to support Haiti's economic reform, which included increased taxes and fiscal reform (IMF, 1996). As a result, protests spread again throughout the country, led by more than 160 grassroots groups, asking for the suspension of the austerity measures. This led yet again to government repression (THE NEW YORK TIMES, 1997).

In 2000, Haiti postponed local and parliamentary elections that had been scheduled for March 19 after 1,000,000 voters were unable to be registered; riots resumed, accompanied by increased levels of remittances amounting to almost $15 \%$ of GDP. Elections were finally held in May, with a second round in August. Human Rights Watch ${ }^{14}$ reported that fraud was conducted by the Fanmi Lavalas party ${ }^{15}$, leading to increased political violence and serious violations of rights to physical integrity. Presidential elections took place in November 2000, marked by violence, demonstrations, and bombings (AVRIL, 2007). President Aristide was elected for a second term in 2001, which would last until 2004, when he was overthrown in the aftermath of another coup d'état. Haitian students organized several antigovernment demonstrations in 2002, 2003, and 2004, and protesters were again the victim of repression (BBC NEWS, 2003). By this time, Haiti had already reached its highest level of remittances: close to $28 \%$ of GDP.

By 2009, remittances in Haiti outnumbered official aid by $123 \%$ and FDI by $3,625 \%$. The total number of Haitians who had left the country amounted to 1,009,400 by 2010 (MPI, 2011). The last peak in protests was in 2014, when three specific demands led people to the streets: the resignation of President Michal Martelly in the aftermath of a corruption scandal; the departure of UN troops; and opposition to the police occupation of the southern island of Ile à Vâche (IVES,

\footnotetext{
13United Nations International Report, Emergency Economic Recovery Program, 1 A1 (1995).

${ }^{14}$ Human Rights Watch, World Report 2001. Available at <https://www.hrw.org/legacy/wr2k1/americas/haiti.html>.

${ }^{15}$ The Fanmi Lavalas Party was ex-President Jean-Bertrand Aristide's party (see Human Rights Watch's World Report, 2001).
} 
2014). Before this period, a decrease in both protest and remittances can be observed, showing the influence and important role of the diaspora.

This case study of Haiti illustrates how remittances and violations of rights to physical integrity are intertwined. Between 1976 and 2014, we identified six moments when increases in remittances were associated with more violations of rights to physical integrity. Haiti is particularly relevant for the causal story that this paper proposes because the Haitian diaspora has always been engaged in Haitian politics; in fact, diaspora channels often triggered the chains of events that culminated in higher levels of repression. As the case of Haiti demonstrates, the diaspora influenced repeated attempts to promote a transition to democracy as well as efforts to hold human rights perpetrators accountable via transitional justice initiatives. Our analysis is complemented by individual-level survey data, which confirms remittances' effect on political engagement.

\section{Conclusion}

This study offers a fresh look at the relationship between migrant remittances and the protection of human rights in migrant-sending countries. Our focus is on rights to physical integrity and our geographic scope is Latin America. Our empirical analysis finds that remittances have a mild (unintended) adverse impact on the protection of human rights to physical integrity. The effect of remittances is small relative to that of political protest, the size of a country's population, and even the imposition of economic sanctions. Nevertheless, it is important, especially because this category of human rights violations implicates very serious violations such as torture, political disappearances, and extra-judicial killings.

This analysis covers 21 Latin American countries over the 1981-2014 period. The choice of Latin America follows from its high numbers of protests and elections. Latin American countries have conducted periodic elections even during dictatorships, such as in Brazil between 1964 and 1985. This is a region in which political protest is frequent and easy to observe, perhaps due to the prevalence of multi-party regimes (VREELAND, 2008). 
A case study of Haiti complements our analysis and highlights the role of the Haitian diaspora. Our analysis of Haiti benefits from individual-level survey data, which confirms the patterns of behavior described in the theoretical section. Corroborating the theory, we show that Haitians, inspired by the diaspora, took to the streets to demand public goods such as democratization and human rights. The presence of remittances relieves households of their most pressing economic needs, thereby enabling individuals to be less dependent on the government for their basic needs.

This analysis suggests that the adverse consequences of remittances for the protection of rights to physical integrity operate via the impact of remittances on political protest. Remittances constitute a particularly strong predictor of repression during election years because the incentives to send remittances are greater during these times, as is the political return in many cases. Our empirical analysis reveals that increases in remittances, measured as in increase to two standard deviations above the mean, increases the probability of rights violations by five percent for countries that are already severe repressors. These results were corroborated by the finding that increasing remittances to two standard deviations above the mean reduces the probability of improvements in rights protection by about three to five percent across all categories on the CIRI scale.

This effort to map the relationship between remittances and rights protection has important implications for both policy and electoral politics. Far from suggesting policy prescriptions, the message conveyed here may raise awareness among human rights advocates regarding the vulnerability of target groups to repression when levels of remittances rise. Likewise, results may inspire opposition groups to strengthen their human rights agendas in anticipation of potential adverse consequences of diasporas' political activities. These findings invite more research on the micro-foundations of this association between migrant remittances and higher levels of government repression. There is also ample opportunity for more research on the consequences of protest, especially during electoral cycles, for the protection of human rights.

Revised by Ryan Lloyd Submitted on February 22, 2019 Accepted on March 05, 2019 


\section{References}

ABOUHARB, M. Rodwan and CINGRANELLI, David L. (2006), The human rights effects of World Bank structural adjustment, 1981-2000. International Studies Quarterly. Vol. 50, № 02, pp. 233-262.

AVRIL, Prosper (2007), Justice versus politics in Haiti (2001-2004). Boca Raton: Universal Publishers. 184 pp..

APODACA, Clair (2007), The whole world could be watching: human rights and the media. Journal of Human Rights. Vol. 06, № 02, pp. 147-164.

BBC NEWS (2003), Haiti protests marred by violence. Available at $<$ http://news.bbc.co.uk/2/hi/americas/3313565.stm>. Accessed on August, 13, 2019.

BECK, Nathaniel and KATZ, Jonathan N. (2011), Modeling dynamics in time-seriescross-section political economy data. Annual Review of Political Science. Vol. 14, pp. 331-352.

BLUNDELL, Richard and BOND, Stephen (1998), Initial conditions and moment restrictions in dynamic panel data models. Journal of econometrics. Vol. 87, № 01, pp. 115-143.

BUCH, Claudia M. and KUCKULENZ, Anja (2010), Worker remittances and capital flows to developing countries. International Migration. Vol. 48, № 05, pp. 89117.

BURGESS, Katrina (2012), Unpacking the diaspora channel in new democracies: When do migrants act politically back home? Studies in Comparative International Development. Vol. 49, № 01, pp. 13-43.

CARNEIRO, Cristiane Lucena (2019), The inter-american human rights system. In: The Institutions of human rights: developments and practices. Edited by DIGIACOMO, Gordon and KANG, Susan L.. Toronto: University of Toronto Press. pp. 202-221.

CARNEIRO, Cristiane Lucena and APOLINÁRIO Jr., Laerte, (2015), Targeted versus conventional economic sanctions: what is at stake for human rights? International Interactions. Vol. 42, № 04, pp. 565-589.

CINGRANELLI, David L.; RICHARDS, David L., and CLAY, K. Chad (2014), The CIRI Human Rights Dataset. Available at < http://www.humanrightsdata.com $>$. Accessed on July, 15, 2017.

COLLIER, Paul and HOEFFLER, Anke (2004), Greed and grievance in civil war. Oxford Economic Papers. Vol. 56, № 04, pp. 563-595. 
CÓRDOVA, Abby and HISKEY, Jonathan (2015), Shaping politics at home: crossborder social ties and local-level political engagement. Comparative Political Studies. Vol. 48, №11, pp. 1454-1487.

COUPEAU, Steeve (2008), The history of Haiti. Westport: Greenwood Publishing Group. 183 pp..

DAVENPORT, Christian (2004), The promise of democratic pacification: an empirical assessment. International Studies Quarterly. Vol. 48, № 03, pp. 539560.

DOYLE, David (2015), Remittances and social spending. American Political Science Review. Vol. 109, № 04, pp. 785-802.

ESCRIBÀ-FOLCH, Abel; MESEGUER, Covadonga, and WRIGHT, Joseph (2015), Remittances and democratization. International Studies Quarterly. Vol. 59, № 03, pp. 571-586.

FAGEN, Patricia Weiss (2006), Remittances in crises: a Haiti case study. London: Overseas Development Institute. 24 pp..

FARISS, Christopher J. (2014), Respect for human rights has improved over time: modeling the changing standard of accountability. American Political Science Review. Vol. 108, № 02, pp. 297-318.

GAVIGAN, Patrick (1997), Migration emergencies and human rights in Haiti. Paper prepared for the Conference on Regional Responses to Forced Migration in Central America and the Caribbean. Department of International Legal Affairs. Office of legal Cooperation.

GERMENJI, E., BEKA, I., and SARRIS, A. (2001). Estimating remittance functions for rural-based Albanian emigrants. ACE Research Project Working. Paper P978158-R.

GIBBONS, Elizabeth D. (1999), Sanctions in Haiti: human rights and democracy under assault. Vol. 177. Santa Barbara: Greenwood Publishing Group. 138 pp..

GLOBAL SECURITY (2011), 1991-1994 - Raul Cedras. Available at $<$ http://www.globalsecurity.org/military/world/haiti/politics-cedras1991.htm>. Accessed on July, 15, 2017.

HILLEBRECHT, Courtney (2012), The domestic mechanisms of compliance with international human rights law: case studies from the Inter-American Human Rights System. Human Rights Quarterly. Vol. 34, № 04, pp. 959-985.

HIRSCHMAN, Albert O. (1978), Exit, voice, and the state. World Politics. Vol. 31, № 01, pp. 90-107. 
HOLLYER, James R., and ROSENDORFF, B. Peter (2011), Why do authoritarian regimes sign the convention against torture? Signaling, domestic politics and non-compliance. Quaterly Journal of Political Science. Vol. 06, № 03-04, pp. 275327.

HUFBAUER, Gary Clyde; SCHOTT, Jeffrey J.; OEGG, Barbara, and ELLIOTT, Kimberly Ann (2007), Economic sanctions reconsidered: history and current policy. Vol. 01. Washington: Peterson Institute for International Economics. 248 pp..

HUMAN RIGHTS WATCH WORLD REPORT (2001), Available at $<$ https://www.hrw.org/legacy/wr2k1/americas/haiti.html $>$. Accessed on July, 30, 2017.

HYDE, Susan D. and MARINOV, Nikolay (2012), Which elections can be lost? Political Analysis. Vol. 20, № 02, pp. 191-210.

ILAHI, Nadeem and JAFAREY, Saqib (1999), Guestworker migration, remittances and the extended family: evidence from Pakistan. Journal of development Economics. Vol. 58, № 02, pp. 485-512.

INTERNATIONAL MONETARY FUND (1996), IMF approves three-year esaf loan for Haiti. Press release № 96/53. Available at $<$ http://www.imf.org/external/np/sec/pr/1996/pr9653.htm>. Accessed on July, 15, 2017.

IVES, Kim (2014), Growing protests in Haiti: thousands demonstrate to demand the Departure of President Martelly and MINUSTAH. Global Research. Available at $<$ http://www.globalresearch.ca/growing-protests-in-haiti-thousandsdemonstrate-to-demand-the-departure-of-president-martelly-andminustah/5378296>. Accessed on July, 15, 2017.

LANDMAN, Todd (2005), Protecting human rights: a comparative study. Washington: Georgetown University Press. 248 pp..

MARSHALL, Monty G. (2015), Major episodes of political violence (MEPV) and conflict regions, 1946-2014. Center for Systemic Peace. Available at

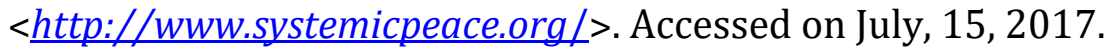

MARSHALL, Monty G. and GURR, Tedd Robert (2010), Center for Systemic Peace. Available at <http://www.systemicpeace.org/polity/polity4.htm>. Accessed on July, 15, 2017.

MESEGUER, Covadonga and BURGESS, Katrina (2014), International migration and home country politics. Studies in Comparative International Development. Vol. 49, № 01, pp. 01-12. 
MESEGUER, Covadonga and Aparicio, Francisco Javier (2012a), Supply or demand? Migration and political manipulation in Mexico. Studies in Comparative International Development. Vol. 47, № 04, pp. 411-440.

MESEGUER, Covadonga and Aparicio, Francisco Javier (2012b), Collective remittances and the state: the $3 \times 1$ program in Mexican municipalities. World Development. Vol. 40, № 01, pp. 206-222.

MESQUITA, Bruce Bueno de; DOWNS, George W.; SMITH, Alastair, and CHERIF, Feryal Marie (2005), Thinking inside the box: a closer look at democracy and human rights. International Studies Quarterly. Vol. 49, № 03, pp. 439-457.

MESQUITA, Bruce Bueno de; SMITH, Alastair; SIVERSON, Randolph M., and MORROW, James D. (2003), The logic of political survival. Massachusetts: MIT Press. 550 pp..

MILLER, Gina Lei and RITTER, Emily Hencken (2014), Emigrants and the onset of civil war. Journal of Peace Research. Vol. 51, № 01, pp. 51-64.

MURDIE, Amanda and DAVIS, David R. (2010), Problematic potential: the human rights consequences of peacekeeping interventions in civil wars. Human Rights Quarterly. Vol. 32, № 01, pp. 49-72.

NYBLADE, Benjamin and O'MAHONY, Angela (2014), Migrants' remittances and home country elections: cross-national and subnational evidence. Studies in Comparative International Development. Vol. 49, № 01, pp. 44-66.

O'MAHONY, Angela (2013), Political investment: remittances and elections. British Journal of Political Science. Vol. 43, № 04, pp. 799-820.

POE, Steven C.; TATE, C. Neal, and KEITH, Linda Camp (1999), Repression of the human right to personal integrity revisited: a global cross-national study covering the years 1976-1993. International studies quarterly. Vol. 43, № 02, pp. 291-313.

POLICZER, Pablo (2006), Human rights violations beyond the state. Journal of Human Rights. Vol. 05, № 02, pp. 215-233.

PREST, Stewart; HARRINGTON, Andrew; UNHEIM, Per; CARMENT, David, and DADE, Carlo (2009), The international peace and conflict dimensions of Jamaican and Haitian diasporas. Human Architecture. Vol. 07, № 04, pp. 15-36.

ROODMAN, D. (2006), How to do xtabond2: an introduction to difference and system GMM in Stata. Center for Global Development Working. Paper № 103.

QUINN, Joanna R. (2009), Haiti's failed Truth Commission: lessons in transitional justice. Journal of Human Rights. Vol. 08, № 03, pp. 265-281. 
SINGER, D. (2012), The family channel: migrant remittances and government finance. MIT Political Science Department Research. Paper № 2012-23.

THE NEW YORK TIMES (1997), Protests erupt across Haiti as leaders push austerity, Available at <http://www.nytimes.com/1997/01/17/world/protests-eruptacross-haiti-as-leaders-push-austerity.html>. Accessed on July, 30, 2017.

SCHOMBURG CENTER FOR RESEARCH IN BLACK CULTURE (2005), Haitian immigration: 20th Century. The New York Public Library. Available at < http://www.inmotionaame.org/migrations/landing.cfm;jsessionid=f830630211 558626235906?migration=12\&bhcp=1>. Accessed on July, 30, 2017.

UNITED NATIONS INTERNATIONAL REPORT (1995), Emergency Economic Recovery Program. Available on <http://www.hartfordhwp.com/archives/43a/050.html $>$. Accessed on July, 30, 2017.

VREELAND, James Raymond (2008), Political institutions and human rights: why dictatorships enter into the United Nations Convention against torture. International Organization. Vol. 62, № 01, pp. 65-101.

WILKINS, Arjun S. (2018), To lag or not to lag? Re-evaluating the use of lagged dependent variables in regression analysis. Political Science Research and Methods. Vol. 06, № 02, pp. 393-411.

WILSON, David L. (2011), Haiti 1994: the forgotten intervention. World War 4 Report. Available at $<$ http://ww4report.com/node/10053 $>$. Accessed on July, 15, 2017.

WOOD, Reed M. (2008), A hand upon the throat of the nation: economic sanctions and state repression, 1976-2001. International Studies Quarterly. Vol. 52, № 03, pp. 489-513.

WORLD BANK (2017), World Development Indicators. Available at $<$ https://databank.worldbank.org/reports.aspx?source=world-developmentindicators $>$. Accessed on July, 15, 2017. 


\section{Appendix A}

Table 06. Correlations between independent variables

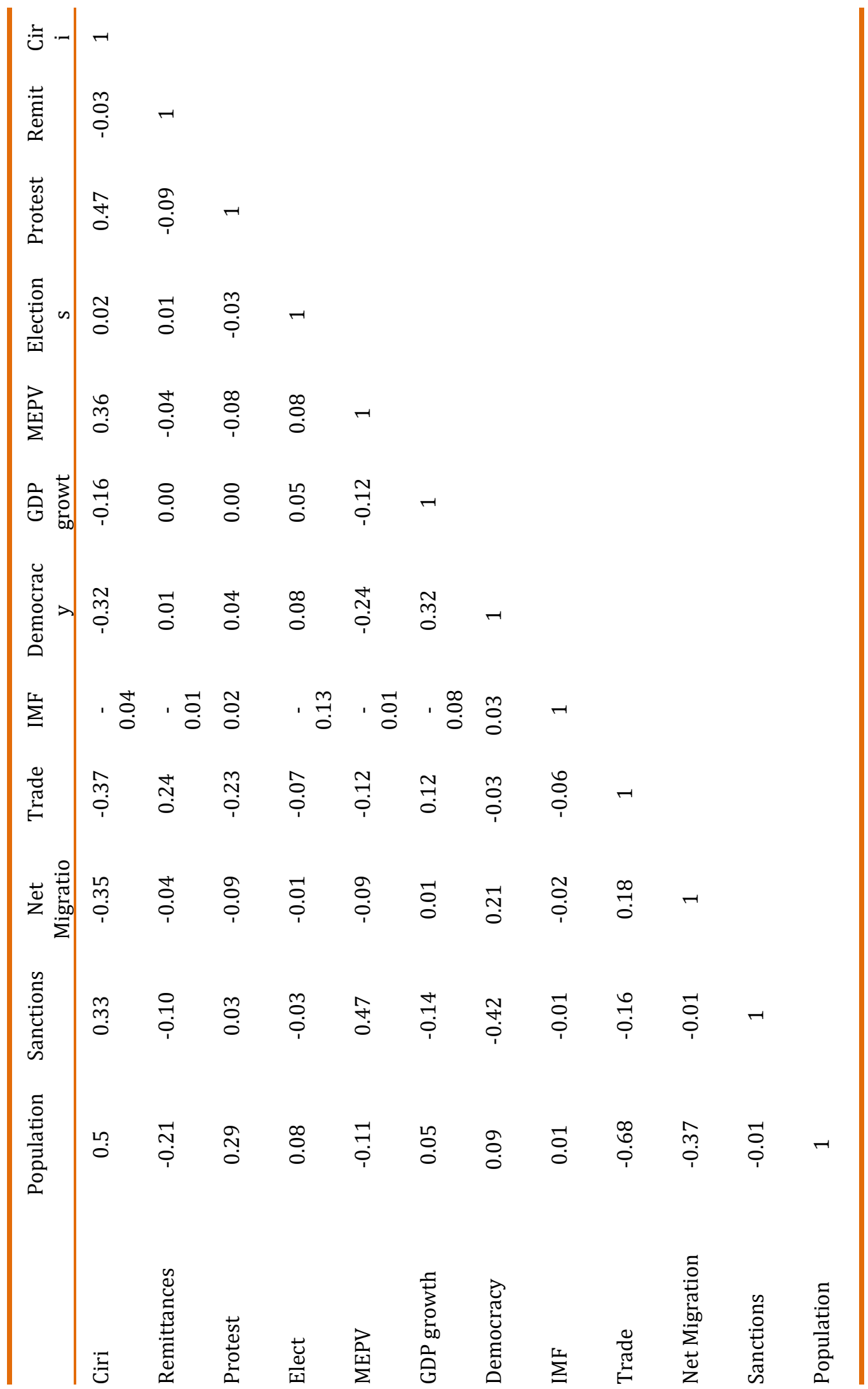

Source: Prepared by the authors. 